\title{
Species identity, richness and developmental stage of morphology affect enzymatic activity of the soil microorganisms in arid Patagonia, Argentina
}

\begin{abstract}
Microbial communities are a key for terrestrial ecosystem functioning. However, their responses to changes in plant species identity and richness, and stages of developmental morphology have been rarely investigated. The objective of this study was to evaluate the impact of the identity, richness and stage of developmental morphology of plant species on soil microbial communities throughout the enzymatic activity of the dehydrogenase. Studies were conducted under wild, field conditions, and on field experimental plots having different species richness. Treatments included a control (intraspecific monocultures) or combinations of 2, 4, or 6 species pertaining to different functional groups (i.e., perennial either grasses or herbaceous dicots or shrubs). The grass Nassella tenuis and the shrub Larrea divaricata showed a lower $(p<0.05)$ activity of the dehydrogenase than most of the other studied species under wild, field conditions. The enzymatic activity of the dehydrogenase was either similar or greater ( $<0.05$; e.g., Amelichloa ambigua, L. divaricata), but not lower, as species richness increased in the reproductive stage of developmental morphology. Finally, the dehydrogenase activity was in general greater $(p<0.05)$ at the reproductive (late spring) than vegetative (late fall) stage of developmental morphology in all studied species. These results indicate that species identity, richness and stage of developmental morphology might be important determinants of the degree of microbial activity in the soil.
\end{abstract}

Keywords: species identity, species richness, soil enzymatic activity, microorganisms, Argentina
Volume 3 Issue 3 - 2019

\author{
Daniela S Cardillo,' Carlos A Busso, 2,3 Mariela \\ L Ambrosino, ${ }^{1,4}$ Yanina A Torres, ${ }^{2,5}$ Leticia S \\ Ithurrart, ${ }^{1,2}$ Rosana ' Palomo ${ }^{3}$ \\ 'Consejo Nacional de Investigaciones Científicas y Técnicas de \\ la República Argentina (CONICET), San Andrés, Argentina \\ ${ }^{2}$ Departamento de Agronomía-Universidad Nacional del Sur \\ (UNS), Argentina \\ ${ }^{3}$ CERZOS- Consejo Nacional de Investigaciones Científicas y \\ Tecnológicas de la República Argentina (CONICET), Argentina \\ ${ }^{4}$ Facultad de Ciencias Exactas y Naturales, Universidad Nacional \\ de La Pampa,Argentina \\ ${ }^{5}$ Comisión de Investigaciones Científicas de la Provincia de \\ Buenos Aires (CIC), Argentina
}

Correspondence: Carlos A Busso, Departamento de Agronomía-Universidad Nacional del Sur (UNS), San Andrés, 8000 Bahía Blanca, Pcia Buenos Aires, Argentina, Email cebusso@criba.edu.ar, carlosbussol@gmail.com

Received: April 03, 2019 | Published: June 03,2019

\section{Introduction}

The residues of plants in the soil are transformed to $\mathrm{CO}_{2}$, microbial material and relatively stable humus compounds. ${ }^{1}$ Decomposition of these plant residues is accompanied by alterations of the responsible enzymes of these transformations, because this is a microorganismmediated process. ${ }^{1}$ Richness, population size of soil microorganisms, and the subsequent enzyme production will depend mostly upon the chemical composition of plant residues. ${ }^{1}$ As a result, chemistry of plant residues not only determines its own destiny but also regulates microbial activity. Such activity is responsible for the release and availability of plant essential nutrients, such as carbon and phosphorous. ${ }^{2}$

Enzymatic activities can give quantitative indications of the changes in the quantity and quality of the organic matter. ${ }^{3}$ For example, the dehydrogenase is present in all undamaged and viable microbial cells. ${ }^{4}$ This enzyme can be a sensible indicator of the effects of soil degradation on the size of soil microbial communities. This is because of this enzyme might be related with the presence of viable microorganisms and their oxidative activities. ${ }^{5}$ The dehydrogenase enzyme appears to be associated with the microbial activity related to the initial break-up of the organic matter. ${ }^{6}$ This enzyme appears to depend more than any other present enzyme from the soil metabolic state or the biological activity of the microbial community. ${ }^{7}$ The dehydrogenases are involved in the transfer of oxidative energy among the microbial cells. ${ }^{8}$ The activity of this enzyme is a measure of the microbial metabolism, and therefore of the soil oxidative microbial activity. ${ }^{9}$ Even more, it indicates the mean activity of the soil organism populations. ${ }^{10}$ Indirectly, this can also indicates the carbon availability and energy source for the soil microorganisms. The dehydrogenase activity has a high correlation with respiration in most studies. This suggests that these activities could be taken as an indicator of the microbial activity ${ }^{3}$ or be used as a whole to establish an activity index. ${ }^{11}$

Hill et al., ${ }^{12}$ reported that soil enzymatic activities could vary seasonally in temperate grasslands. The seasonal variations in microbial biomass and enzymatic activities in the soil are due to the combined effects of temperature, humidity, substrate availability and other factors. ${ }^{13}$ Dehydrogenases pertain to the enzymes that have strong fluctuations on their activity caused by the season of the year, since they are strongly associated with the dynamics of the microbial activity. ${ }^{13}$ Much research has been done on the effects of temperature on the dehydrogenase activity in the soil and/or on the soil microorganisms abundance. ${ }^{14,15}$ The dehydrogenase is found only in viable cells of soil microorganisms. Therefore, its activity must be high at an optimal temperature that allows their growth and development. ${ }^{13}$ The speed of enzymatic catalysis increases as temperature increases until a temperature is reached where the enzyme is denaturalized and its activity is reduced. However, the seasonal changes during a year, and those related with the plant developmental morphology stages have rarely been related to the enzymatic activity of the dehydrogenase in the soil.

Some studies have measured various biological processes in the soil in response to plant species richness (e.g., physico-chemical 
properties, soil enzyme activities, functional diversity, etc). ${ }^{16-19}$ The evidence suggests that plant species richness has significant impacts not only in the soil physico-chemical properties but also more directly on the composition and activity of the soil microbial communities. ${ }^{20}$ Plants can influence the enzymatic activity in the soil throughout the excretion of enzymes, and affect the composition and diversity of the soil microbial species throughout the release of exudates and oxygen in the rhizosphere. Thus, the species of soil microbes can indirectly affect the enzymatic activity. ${ }^{21}$ We expect that plant species richness can influence the activity of the dehydrogenase because the quality and quantity of the root exudates can vary among the different plant species. ${ }^{22}$ Identity and richness of plant species are the major factors that affect the abundance and diversity of soil organisms. ${ }^{23,24}$

Above and belowground ecosystem components depend implicitly one from each other. ${ }^{18}$ The loss of plant species in some ecosystems can produce changes in the community of soil decomposers that in turn can affect the soil organic matter mineralization. ${ }^{25}$ Despite the recognition that microbial communities are the key for terrestrial ecosystem functioning, their response to changes in plant species richness have been rarely investigated. ${ }^{26,27}$

Our objective was to evaluate the impact of the identity and richness, and of the stage of developmental morphology, of plant species on soil microbial communities throughout the enzymatic activity of the dehydrogenase. Studies were conducted under wild, field conditions, and on field experimental plots having different species richness. Working hypotheses were (1) plant species differ in the activity of the study enzyme, (2) the enzymatic activity of the dehydrogenase increases as plant species richness also increases, and (3) the activity of the dehydrogenase differs between the vegetative and reproductive stages of developmental morphology of the study plant species.

\section{Materials and methods}

\section{Study site}

This study was conducted at two different sites in the Chacra Experimental Patagones, southwest of the Province of Buenos Aires $\left(40^{\circ} 39^{\prime} 49.7^{\prime}\right.$ S, 62 $2^{\circ} 53^{\prime} 6.4^{\prime \prime} \mathrm{W} ; 40 \mathrm{~m}$ a.s.1), within the Phytogeographical Province of the Monte during 2013 and 2014. ${ }^{28}$ One site (i.e., the "'Monte" from here on; 240 ha) had been overgrazed until 1980. Thereafter, it was fenced and vegetation recuperation was allowed on it until $1996,{ }^{29}$ when a rotational grazing system was initiated with an annual mean stocking rate of 7.8 ha per cow. ${ }^{30}$ The other, nearby site ( $1 \mathrm{~km}$ apart one from each other), was a 7 -yearexclosure to domestic livestock of 0.025 ha (i.e., experimental plots).

\section{Climate}

It is temperate semi-arid, with precipitations concentrated in summer and autumn. Annual mean precipitation was $421 \mathrm{~mm}$ during 1981-2012, with minimum and maximum values of 196mm (2009) and $877 \mathrm{~mm}$ (1984), respectively. ${ }^{31}$ Precipitation, evapotranspiration, air and soil temperatures, and relative humidity (Figure 1) were determined by an automatic meteorological station located a few meters away from the experimental plots (Figure 2). Total annual precipitation was $513 \mathrm{~mm}$ during 2012, 422 $\mathrm{mm}$ during 2013, and $597 \mathrm{~mm}$ during 2014.
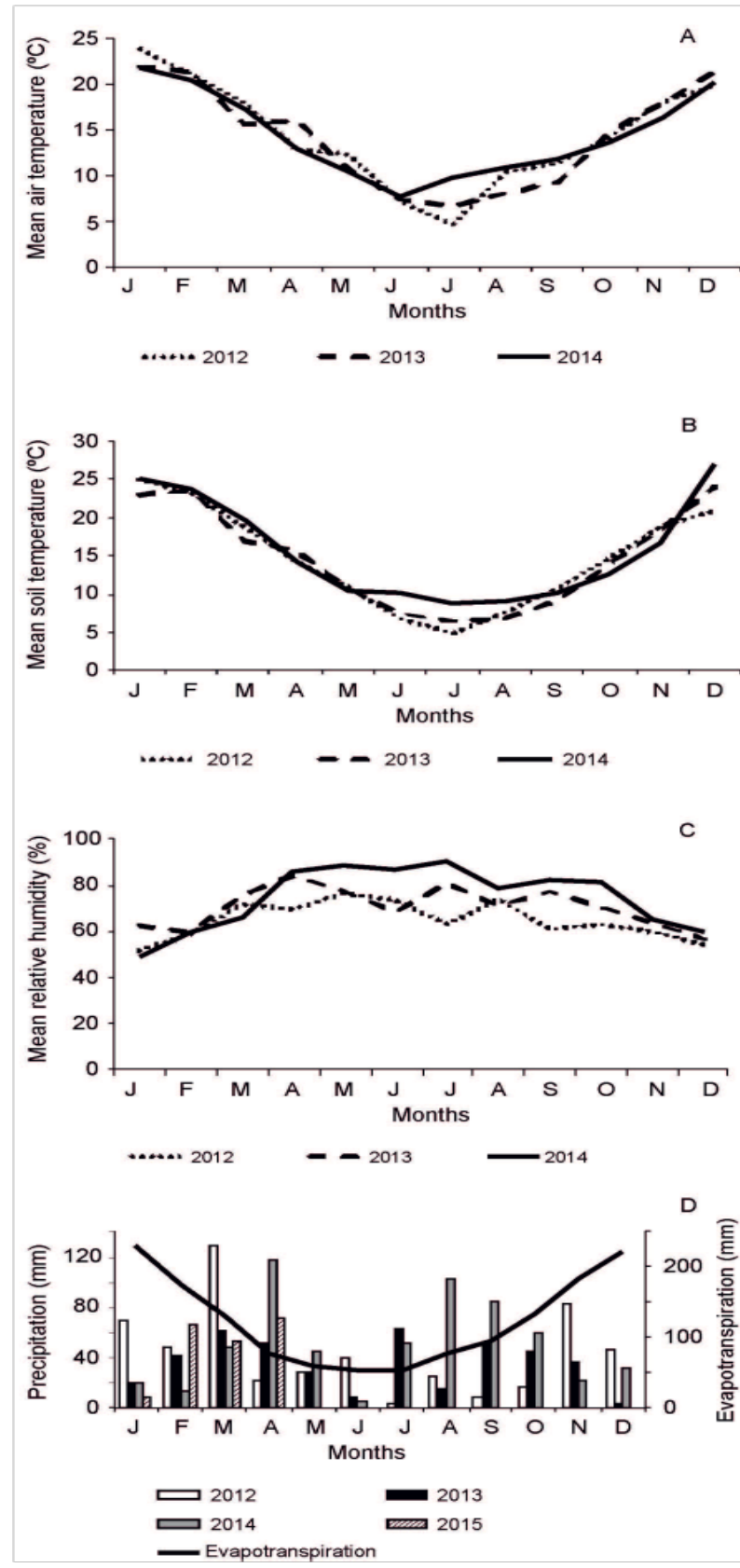

Figure I (a and b) Mean air and soil $\left(0-20 \mathrm{~cm}\right.$ depth) temperatures $\left({ }^{\circ} \mathrm{C}\right)$, (c) mean relative humidity (\%), (d) mean evapotranspiration and monthly precipitation during 2012 to 2015 .

\section{Soil}

Landscape on the region is mostly a plain, although there are waves and isolated micro-depressions. The original materials of the predominant soils are fine sands, which are transported by wind and deposited on "'tosca", and older, weakly consolidated siltysandy materials (INTA-CIRN, 1989). Soil was classified as a typical Haplocalcid (Nilda Mabel Amiotti, Dpto. de Agronomía UNSur, 
Bahía Blanca, Argentina, personal communication). Mean $\mathrm{pH}$ is 7 and there are no limitations of depth in the soil profile. ${ }^{32}$

\section{Vegetation}

The plant community is an open shrubby stratum that includes herbaceous species of different quality for livestock production. ${ }^{32}$ Nassella longiglumis (Phil.) Barkworth, ${ }^{33}$ Nassella tenuis (Phil.) Barkworth (an intermediate-seral species, ${ }^{34}$ and Pappostipa speciosa and Amelichloa ambigua (Speg.) Arriaga \& Barkworth (earlier seral species) are $\mathrm{C}_{3}$ native perennial grasses in the Phytogeographical Province of the Monte, Argentina. This Province includes approximately 554,138 ha in the Partido de Patagones, Province of Buenos Aires. Dominance of these species in the community depends, at least in part, of the grazing history, and frequency and intensity of fires..$^{33}$ Characteristic rangeland management at the south of this region is continuous grazing with excessive stocking rate. ${ }^{35}$ Pappostipa speciosa and Amelichloa ambigua have a low preference by grazing animals, ${ }^{36}$ while $N$. longiglumis and $N$. tenuis are highly preferred. As a result, $N$. longiglumis and $N$. tenuis might be highly selected by domestic herbivory at different times during their developmental morphology stages. The either low frequency or lack of fires combined with severe livestock overgrazing, diseminule availability of shrub species, and conditions which foster their seedling establishment have contributed to the (1) replacement of preferred by unpreferred perennial grasses, (2) establishment of annual species in the open, unvegetated areas during wet years, and (3) establishment of shrubby vegetation such as Condalia microphylla, Larrea divaricata Cav., and Schinus fasciculatus (Griseb.) I.M. Johnst., and the perennial forb Atriplex semibaccata $\mathrm{R} . \mathrm{Br}^{37}$

\section{Transplanting of plants to the experimental plots}

The method to obtain plants of $N$. longiglumis, $N$. tenuis and $A$. ambigua was by cloning these tussock, perennial grasses. Transplanting of small individuals from the field to plastic pots was the method used to obtain plants of the shrubs $L$. divaricata and $S$. fasciculatus, and the forb A. semibaccata. Various studies were successful in obtaining plants of A. semibaccata via transplanting. ${ }^{38}$ Individuals of these species obtained via either cloning or transplanting were placed in 1.5 liter pots. These pots contained soil coming from the study field site, which was previously cleaned from residues using a 35-mesh screen. These pots were placed in a greenhouse and watered periodically. They were cleaned manually from emerging weeds. After a period of 6 months in the greenhouse, plants were allowed to acclimate to environmental conditions outside of it during 3 months before transplanting.

At the beginning of October 2012 the soil in the 0.025 ha exclosure was prepared before transplanting. This was because it was compacted as a result of previous studies. ${ }^{39,40}$ With the purpose of having a loose soil, weed control and soil aeration, tillage was conducted twice. In addition, the soil was further cleaned twice with a rake, and also twice using a cultivator. Plant cover was controlled to a depth of $20 \mathrm{~cm}$ approximately. Afterwards, experimental plots $(1.25 \times 1.25 \mathrm{~m}$ each) were established in the exclosure (Figure 2). During a month, 1944 plants were transplanted in that exclosure.

\section{Experimental design}

\section{Experimental plots}

Fifty four experimental plots were used in this study [4 treatments (monocultures of each of the 6 species, and combinations of 2, 4 and 6 plant species: Figure 2) x 6 replicates/treatment (i.e., 6 blocks, Figure 2)]. Each block contained monocultures of each of the study species (i.e., $N$. tenuis, $N$. longiglumis, A ambigua, A. semibaccata, $S$. fasciculatus and L. divaricata), and a plot with mixtures of $2(N$. tenuis and A. semibaccata; Figure 3), 4 (N. tenuis, A. semibaccata, $N$. longiglumis and S. fasciculatus; Figure 3) or 6 species (N. tenuis, $N$. longiglumis, A. ambigua, A. semibaccata, $S$. fasciculatus and $L$. divaricata; Figure 3 ) following a substitute design (i.e., plant density was equal in all study plots). The combination of species on each row of the 2, 4 or 6 species combination was at random (Figure 3). Six hundred and twenty nine plants were reserved to replace dead plants in the plots [629 +1944 plants from the plots ( 54 plots x 36 plants per plot: Figure 2 \& Figure 3) $=2573$ plants in total].

Each experimental plot $(1.25 \times 1.25 \mathrm{~m})$ contained 36 plants, and each of the 6 blocks contained the 1 (i.e., monocultures), 2, 4, or 6 plant species combinations (Figure 3). Vertical and horizontal distances among plants within each plot was $0.25 \mathrm{~m}$ in all plant species combinations.

\section{Block number}
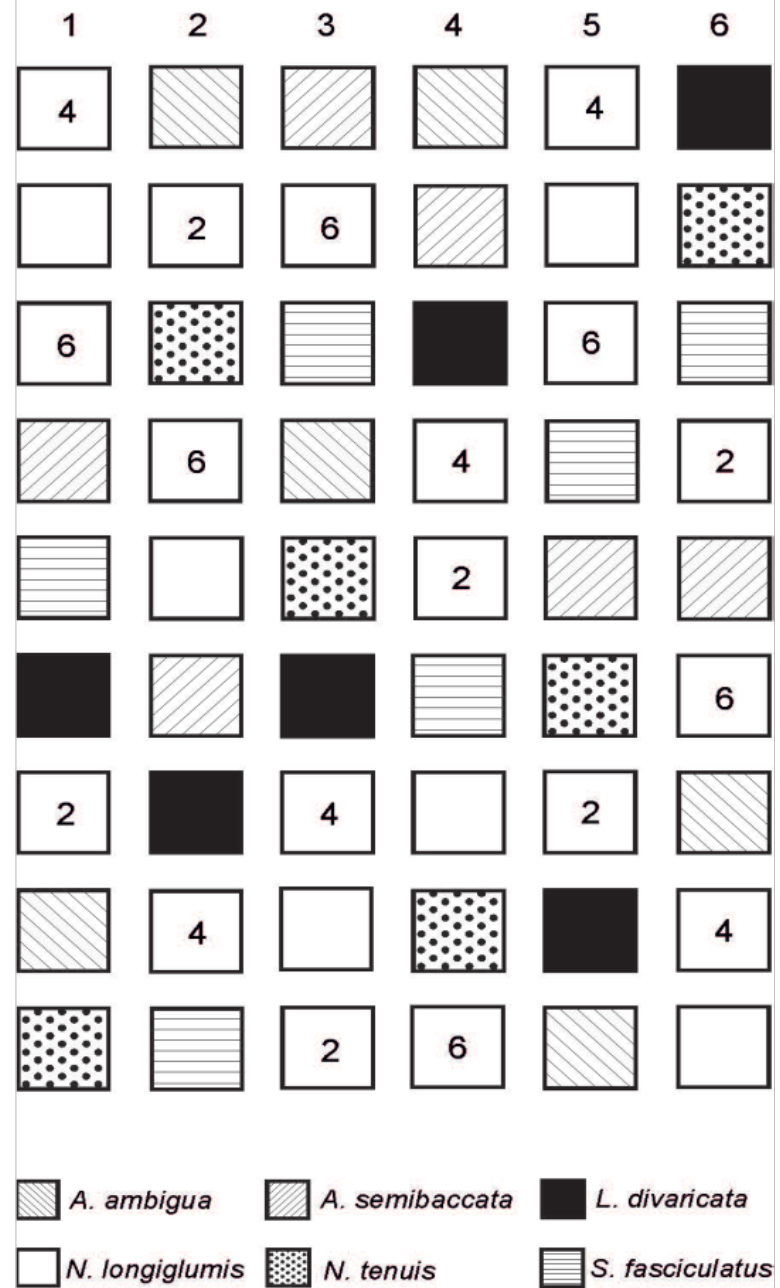

Figure 2 Diagram showing the distribution of the monocultures of each of the 6 species and the combination of 2, 4 and 6 species within each of the six experimental blocks. Distance among individual species was $0.25 \mathrm{~m}$ in horizontal and vertical lines. 
COMBINATION OF TWO SPECIES

\begin{tabular}{|l|l|l|l|l|l|}
\hline$N_{t}$ & $A_{s}$ & $N_{t}$ & $A_{s}$ & $N_{t}$ & $A_{s}$ \\
\hline$A_{s}$ & $N_{t}$ & $A_{s}$ & $N_{t}$ & $A_{s}$ & $N_{t}$ \\
\hline$N_{t}$ & $A_{s}$ & $N_{t}$ & $A_{s}$ & $N_{t}$ & $A_{s}$ \\
\hline$A_{s}$ & $N_{t}$ & $A_{s}$ & $N_{t}$ & $A_{s}$ & $N_{t}$ \\
\hline$N_{t}$ & $A_{s}$ & $N_{t}$ & $A_{s}$ & $N_{t}$ & $A_{s}$ \\
\hline$A_{s}$ & $N_{t}$ & $A_{s}$ & $N_{t}$ & $A_{s}$ & $N_{t}$ \\
\hline
\end{tabular}

\section{COMBINATION OF FOUR SPECIES}

\begin{tabular}{|l|l|l|l|l|l|}
\hline$S_{f}$ & $A_{s}$ & $N_{I}$ & $N_{t}$ & $S_{f}$ & $A_{s}$ \\
\hline$N_{I}$ & $A_{s}$ & $N_{I}$ & $N_{t}$ & $S_{f}$ & $N_{t}$ \\
\hline$A_{s}$ & $N_{I}$ & $N_{t}$ & $S_{f}$ & $A_{s}$ & $N_{I}$ \\
\hline$S_{f}$ & $A_{s}$ & $S_{f}$ & $A_{s}$ & $N_{I}$ & $A_{s}$ \\
\hline$N_{t}$ & $S_{f}$ & $A_{s}$ & $N_{I}$ & $A_{s}$ & $A_{s}$ \\
\hline$N_{l}$ & $S_{f}$ & $N_{t}$ & $N_{l}$ & $A_{s}$ & $S_{f}$ \\
\hline
\end{tabular}

COMBINATION OF SIX SPECIES

\begin{tabular}{|l|l|l|l|l|l|}
\hline$N_{t}$ & $L_{d}$ & $N_{I}$ & $A_{s}$ & $A_{a}$ & $S_{f}$ \\
\hline$N_{l}$ & $A_{a}$ & $N_{l}$ & $S_{f}$ & $L_{d}$ & $A_{s}$ \\
\hline$N_{l}$ & $N_{t}$ & $L_{d}$ & $S_{f}$ & $A_{s}$ & $L_{d}$ \\
\hline$L_{d}$ & $S_{f}$ & $N_{t}$ & $L_{d}$ & $A_{s}$ & $S_{f}$ \\
\hline$S_{f}$ & $N_{l}$ & $A_{s}$ & $A_{a}$ & $N_{l}$ & $N_{l}$ \\
\hline$A_{s}$ & $S_{f}$ & $A_{a}$ & $N_{t}$ & $S_{f}$ & $A_{a}$ \\
\hline
\end{tabular}

Figure 3 Experimental plots showing the combination of the 2, 4 or 6 plant species. Individual plants were separated $0.25 \mathrm{~m}$ one from another in horizontal and vertical rows. The drawing is not made to scale. $\mathrm{A}=$ Amelichloa ambigua; $\mathrm{A}_{\mathrm{s}}=$ A. semibaccata; $\mathrm{N}_{\mathrm{t}}=$ Nassella longiglumis; $\mathrm{N}_{\mathrm{t}}=\mathrm{N}$. tenuis; $\mathrm{L}_{\mathrm{d}}=$ Larrea divaricata; $\mathrm{S}_{\mathrm{f}}=$ Schinus fasciculatus.

\section{Measurements}

\section{Wild, field conditions}

Soil samples under wild, natural field conditions were obtained in a 22 ha paddock exposed to a rotational grazing system. Plants used as controls were those located at least $2 \mathrm{~m}$ apart one from each other in open spaces (i.e., control plants). Seven perennial species, predominant in the region, of two different functional groups, were selected for this study. They included three shrub (Condalia microphylla, Larrea divaricata, Schinus fasciculatus) and four grass species (Nassella longiglumis, Nasella tenuis, Pappostipa speciosa and Amelichloa ambigua). Species of shrubs were young and no greater than $50 \mathrm{~cm}$-height. Four patches were selected where most species of the two functional groups were present. Species distribution was similar in all patches.

The deshydrogenase activity in the soil was determined following Cassida ${ }^{41}$ and Sajjad et al. ${ }^{2}$ This method is based on the use of a soluble salt such as the 2,3,5-triphenil tetrazolium chloride (TTC) as a final electron acceptor. After incubating the soil samples during $24 \mathrm{~h}$ to $37^{\circ} \mathrm{C}$, the study salt was reduced to tryphenil-tetrazolium-formazan (TTF), of red color. Once the TTF was extracted with a disolvent such as acetone, its concentration was quantified by colorimetry. ${ }^{42}$

\section{Calibration curve preparation (following Cassida, 1977)}

Ten $\mathrm{ml}$ of a TTF solution at $0.1 \%(\mathrm{v} / \mathrm{v})$ were diluted with acetone to a final volume of $100 \mathrm{ml}\left(100 \mu \mathrm{g} \mathrm{TTF} \mathrm{ml}^{-1}\right)$. Aliquots of $0.5 ; 2.5 ; 5$; 7.5 , and $10 \mathrm{ml}$ were obtained from that solution, which were placed in $50 \mathrm{ml}$ flasks. Finally, all of them were brought to a $50 \mathrm{ml}$ volume with acetone. These aliquots gave TTF concentrations between 1 and $20 \mu \mathrm{g}$ $\mathrm{ml}^{-1}$. Absorbance was read at $485 \mathrm{~nm}$. Acetone was used as a control. Absorbance values were graphed versus the TTF concentration in the standard solution.

\section{Procedures}

Three grams of fresh soil were weighed in a Falcón flask. One ml of TTC at $3 \%$ and $4 \mathrm{ml}$ buffer (buffer Tris- $\mathrm{HCl} 0.1 \mathrm{M} \mathrm{pH}=7.6-7.8$ ) were added into the flask. Thereafter, a control without TTC was prepared, adding only $0.5 \mathrm{ml}$ of distilled water, and the flask was shaken. Flasks were incubated to $37^{\circ} \mathrm{C}$ during $24 \mathrm{~h}$. After this time, $10 \mathrm{ml}$ of acetone were taken with a pipette, and added to the soil to stop the reaction. It was manually agitated, and then using an orbital agitator during 30 minutes at $300 \mathrm{rpm}$. It was then centrifuged during 10 minutes at $4000 \mathrm{rpm}$, and finally the supernatant was filtered using filter paper in wide test tubes. Absorbance was measured at $485 \mathrm{~nm}$ (Spectronic-20, Bousch abd Lomb), and the concentration was calculated using the calibration curve.

The dehydrogenase activity in soils was expressed as $\mu \mathrm{g} \mathrm{TTF} / \mathrm{g}$ soil $^{-1} \cdot \mathrm{d}^{-1}$. Absorbance values obtained in the analyzed samples were interpolated in the calibration curve to obtain the TTF concentrations. Soil controls were used as blanks. The following formula was used to obtain the activity on each study sample:

$\mathrm{A}_{\mathrm{D}}=\mathrm{V} \cdot\left[(\mathrm{TTF})_{\mathrm{m}}-(\mathrm{TTF})_{\mathrm{c}}\right] / \mathrm{S}_{\mathrm{c}}$

where $A_{D}=$ activity of the dehydrogenase, in $\mu \mathrm{TTF} / \mathrm{g}$ dry soil ${ }^{-1} \mathrm{~d}^{-1}$ 
$(\mathrm{TTF})_{\mathrm{m}}=$ concentration of TTF in the soil sample, in $\mu \mathrm{g} / \mathrm{mL}$

$(\mathrm{TTF})_{\mathrm{c}}=$ concentration of TTF in the control, in $\mu \mathrm{g} / \mathrm{mL}$

$\mathrm{S}_{\mathrm{c}}=$ soil dry weight from $3 \mathrm{~g}$ of wet soil, in $\mathrm{g}$

$\mathrm{V}=$ volume of acetone added to the suspensión, in ml. It was considered that the final volume were $15 \mathrm{ml}(5 \mathrm{ml}$ buffer $+10 \mathrm{ml}$ acetone) for each of $3 \mathrm{~g}$ soil.

\section{Statistical analysis}

A three-way ANOVA was first conducted to study the effects of the species identity ( $N$. longiglumis, $N$. tenuis, $P$. speciosa, A. ambigua, S. fasciculatus, L. divaricata, C. microphylla), location (patches or open spaces) and developmental stages of morphology (i.e., dates: May, November) on the enzymatic activity of the soil microorganisms under wild, field conditions in 2013. However, differences between dates were so great $(p<0.001)$ that a two-way ANOVA was conducted later with species and species location as factors. In the experimental plots, initially, a three-way-ANOVA was made on the plots, where factors were years, and species identity and richness. We compared first the plots with monocultures versus those where the 6 species were combined (i.e., 1 vs. 6). Because this comparison was significant, apriori contrasts were conducted among the factors. Whenever it was a two-way interaction between any of the study factors, a two-wayANOVA was conducted to study the interaction. To study the effects of species richness for each of the study species separately, a block design with 2 factors [the treatments (fixed) and the developmental morphology stages (considered as random)] was utilized. The evaluated variable was the enzymatic activity. Treatments consisted of the number of species present on the experimental unit combinations of 2 (N. tenuis, A. semibaccata), 4 (Schinus fasciculatus, Atriplex semibaccata, Nassella longiglumis, N. tenuis), or 6 species (Nassella longiglumis, Schinus fasciculatus, Nassella tenuis, Atriplex semibaccata, Amelichloa ambigua and Larrea divaricata) versus their respective monocultures. Each of the 54 plots (Figure 2) contained 36 plants (Figure 3 ). The number of blocks was 6 (Figure 2).

Since it was a mixed two-way-ANOVA(treatments $\mathrm{x}$ developmental morphology stages), the interaction was first tested. When it was significant $(p<0.05)$, the mean square (MS) of the interaction was utilized as the MS of the error for treatment comparisons. If it was not significant ( $p>0.05)$, the residual MS was used as error. In all cases, the comparison among means was conducted by averaging the four sampling dates (2 in 2013 and 2 in 2014). Mean comparisons were made using the Dunnett's test. ${ }^{43}$

\section{Results}

\section{Effects of the identity and richness of plant species under wild, field conditions on the soil enzymatic activity at different stages of developmental morphology}

The difference between the reproductive (November 2013) and the vegetative (May 2013) stages of developmental morphology was so great $(\mathrm{p}<0.001)$ (data not shown) that dates were analyzed separately.

Enzymatic activity in the rizhosphere of $N$. longiglumis, $P$. speciosa, and $S$. fasciculatus was greater $(\mathrm{p}<0.05)$ than that in $N$. tenuis and A. ambigua within the vegetation patches exposed to wild, field conditions at the vegetative stage of developmental morphology (Figure 4A). At this stage of developmental morphology and in the open spaces, enzymatic activity was greater $(\mathrm{p}<0.05)$ on $N$. longiglumis and $S$. fasciculatus than in the remaining plant species (Figure 4A). The enzymatic activity in the rhizospheres of $P$. speciosa, L. divaricata and C. microphylla was greater $(\mathrm{p}<0.05)$ when these species were in the vegetation patches than in the open spaces in May 2013.

Schinus fasciculatus showed a greater $(\mathrm{p}<0.05)$ enzymatic activity than the remaining species, except $N$. longiglumis and P. speciosa, in the vegetation patches at the reproductive stage of developmental morphology (Figure 4B). In November 2013, all species showed a similar ( $>0.05)$ enzymatic activity at the vegetation patches than in the open spaces (Figure 4B). At this time, within each species there was not significant differences ( $p>0.05)$ in enzymatic activity weather species grew up in patches or open spaces (Figure 4B).

\section{Species identity and richness effects on the activity of the dehydrogenase in the soil on experimental plots}

Even though the difference was only significant $(\mathrm{p}<0.05)$ on $A$. ambigua and $L$. divaricata, there was a general tendency for an increased enzymatic activity as species richness increased in the experimental plots (Figure 5).

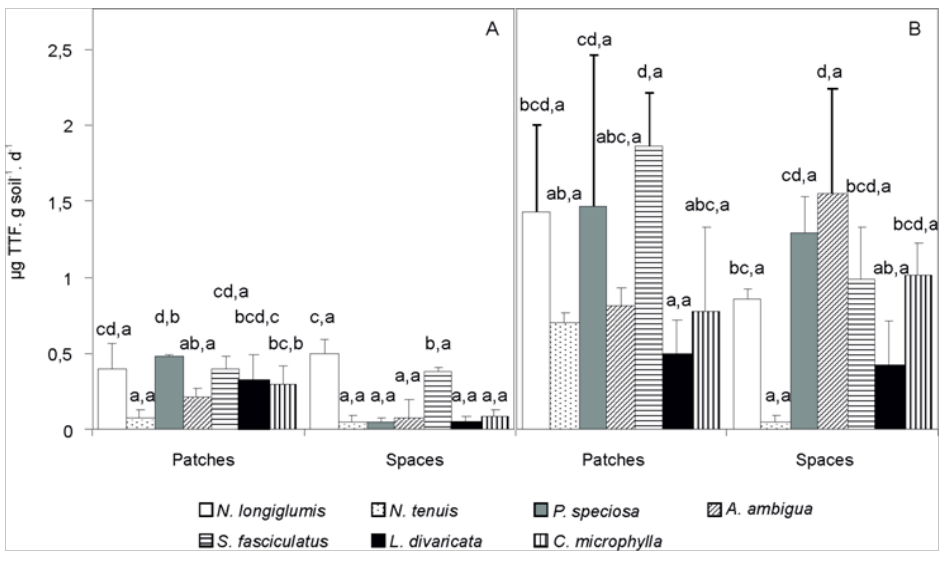

Figure 4 Enzymatic activity of the dehydrogenase $\left(\mu \mathrm{g} T \mathrm{TF} . \mathrm{g}^{-1} \cdot \mathrm{d}^{-1}\right)$ in the soil underneath seven plant species present in vegetation patches or open spaces (any plant was away from any other within a radio of $2 \mathrm{~m}$ ) under wild, field conditions in May 2013 (A, vegetative stage of developmental morphology) and November 2013 (B, reproductive stage of developmental morphology). The control were the species without nearby neighbors (i.e., open spaces). Each data is the mean + I standard error of $n=4$. Within each bar, different letters before the comma indicate significant differences ( $p<0.05)$ among species within each location (patches or open spaces). Different letters after the comma indicate significant differences $(\mathrm{p}<0.05)$ between vegetation patches or open spaces (control) within each species under wild, field conditions. 


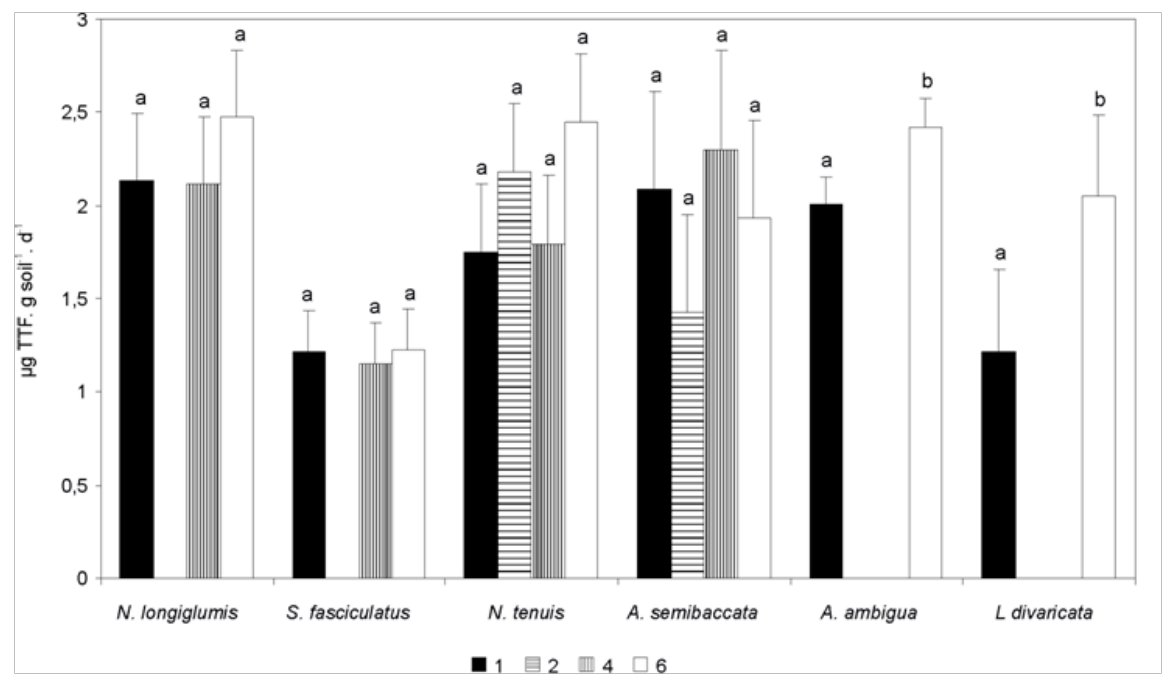

Figure 5 Enzymatic activity of the dehydrogenase ( $\mu \mathrm{g}$ TTF. $\left.\mathrm{g}^{-1} \cdot \mathrm{d}^{-1}\right)$ as a function of species richness (i.e., I, 2, 4 or 6 species) within each species. Each bar is the mean of $n=12+1$ standard error. Different letters indicate significant differences $(p \leq 0.05)$ among species richness within each species.

\section{Discussion}

Results found for basal soil respiration in soils under wild, field conditions ${ }^{44}$ did not agree with those found in this study for the activity of the dehydrogenase at the same location, where the greater activity of that enzyme was shown in November, during the reproductive developmental morphology stage, and the lower one in May, at the vegetative stage of developmental morphology. Hill et al., ${ }^{12}$ reported that the soil enzymatic activities could vary seasonally in rangelands of temperate climates. Bastida et al. ${ }^{45}$ also indicated that seasonality affects soil enzymatic and microbial biomass. Field measurements have the problem of the potential masking effect of the climatic conditions, which change from one to the following soil sample. ${ }^{46}$ A greater soil moisture percentage and a higher soil temperature have favored the activity (both soil respiration and the activity of the dehydrogenase) of soil microorganisms in various studies. ${ }^{47-49}$ Precipitation and air temperature were greater in November (spring) than May (fall) in our study (Figure 1). This must have contributed to obtain a greater microbial activity by both methods in spring in our research: $\mathrm{CO}_{2}$ production from the soil, and the activity of the dehydrogenase enzyme in the soil.

Our dehydrogenase values agree with those reported by Gili et al., ${ }^{50}$ in soils of the Provinces of Rio Negro and Neuquén (in Argentina). In this study, the dehydrogenase activity responded differently than the basal soil respiration ${ }^{44}$ despite of such enzyme is in the microorganisms. Similar results were found by Skujins ${ }^{51}$ and Frankerberger et al., ${ }^{52}$ after making soil microbiological measurements. The lack of a similar response between the enzymatic activity and the microbial respiration might be due to that the enzymatic activity (1) is mostly extracellular under wild conditions, and is not associated with the microbial population, and/or (2) is originated from a source that is not microbial such as the plant roots and the soil organic residues. ${ }^{52}$ The physicochemical soil properties are also important in affecting microbial growth and activity. ${ }^{52}$

Studies on soil biological processes have been based in measuring various variables: microbial biomass, ${ }^{53}$ respiration, ${ }^{54}$ ATP and enzymatic activities ${ }^{52-56}$ However, Nannipieri et al., ${ }^{57}$ suggested that there are problems if variables like carbon biomass, the release of $\mathrm{CO}_{2}$ or the enzymatic activity of the dehydrogenase are only considered as indexes of microbiological activity. These problems are even greater when complex systems as those of arid zones are considered, since these are exposed to great environmental imbalances..$^{50}$ Dehydrogenase values found by various authors ${ }^{50,58}$ in different soil types have been generally greater than those found in this study, where we worked with arid soils. This is similar to that reported by Gili et al., ${ }^{50}$ with regard to the complexity of the systems in soils of arid zones.

Under wild, field conditions, the greater dehydrogenase activity found in the reproductive than in the vegetative developmental morphology stage in 2013 could be due to the fast microclimate changes and the exhaustion of carbon compounds. These lead to a turnover of the microbial community, with the subsequent release of $\mathrm{N}$ to the plants. ${ }^{59}$ Spring is strongly related with increases in the microbial activity, oxide-reduction reactions and temperature changes. All this indirectly affects the dehydrogenase activity, and could be the reason for the dehydrogenase increase during that season. ${ }^{13}$ In addition, and taking into account that dehydrogenase is present within the viable microbial cells, its activity must be greater at temperaturas of $20-30^{\circ} \mathrm{C}$. This temperature range is characteristic for summer and early-fall times, and it is close to the optimum for microbial growth, activity and microorganism development. ${ }^{13}$

When species were at the reproductive stage in the wild, field vegetation patches, the rhizosfere of $L$. divaricata showed the lower enzymatic activity. At the same time $N$. longiglumis, $P$. speciosa and $S$. fasciculatus, showed a very high enzymatic activity. The same pattern was demonstrated in the open spaces. Working with three halophyte species of different functional groups, Cao et al. ${ }^{60}$ found that community composition influenced the enzymatic activity. The dehydrogenase activity was significantly greater on soil of the grass than on that of the shrub community. This might be due because of the herbaceous plants most likely had their root systems within the soil volume sampled in this study $(0-15 \mathrm{~cm}$ soil depth from the soil surface). Soil physicochemical and biological properties change with increasing depth of the soil surface. ${ }^{61}$ Also, the soil organic matter $(\mathrm{OM})$ in the rhizosphere of $L$. divaricata might have also influenced 
the lower enzymatic activity. The OM has important effects not only on the soil enzymatic activities but also on the microbial activities. ${ }^{13}$ Not only the amount but also the quality of OM is important in the soil, since the OM affects the energy supply for microbial growth and enzyme production. ${ }^{62}$ The chemical composition of $L$. divaricata leaves might have affected the dehydrogenase activity in the soil. Studies have been conducted in other species of the Larrea genus which indicate the presence of phenols and compounds against fungi in their resin. ${ }^{63}$ If nitrification is inhibited by tannines and other plant aromatic compounds, ${ }^{64}$ these might also have consequences on the activity of the general microbial community.

Pappostipa speciosa, L. divaricata and C. microphylla showed a greater enzymatic activity in their rhizospheres when these species grew within vegetation patches than when they did in the open spaces in May 2013. The lack of differences between functional groups might be due to the specific richness within the vegetation patches. Nassella tenuis was the species that showed the lower enzymatic activity in the open spaces in November 2013. Studies conducted by Quilchano et al., ${ }^{65}$ suggested that cleaning of Mediterranean forests from shrubs could negatively affect the soil dehydrogenase, and the impact is greater during the dry season. Soils with low soil moisture percentages have a lower microbial activity. ${ }^{49}$ Soil temperature also plays an important role. Brzezinska et al., ${ }^{47}$ reported that the dehydrogenase activity specially increased in water-saturated soils, and this increase was more noticeable at higher temperatures. The dehydrogenase activity increases considerably when temperatures reach $37^{\circ} \mathrm{C} .{ }^{49}$ Under wild environmental conditions, where changes in temperature and moisture are sometimes extremes, there will be corresponding changes in the microbial populations and communities, and in the processes that they cause. As a result, it is believed that the studies to an ecosystem scale offer the best possibility for a rapid evaluation of the changes in soil quality. ${ }^{66}$

However, Mirás Avalos et al., ${ }^{67}$ demonstrated that there exists a marked paralelism between the soil dehydrogenase activity and the soil moisture content, while this paralelism is not so clear for the basal soil respiration. These results appear to indicate that the dehydrogenase activity, basal soil respiration and soil moisture content are related among themselves, but there might exist some other factor/s which might be involved in their seasonal behavior. García et al. ${ }^{56}$ hyphothesized that the major cause of the low microbiological activity in soil of arid zones is the low capacity of the organic matter for being mineralized rather than its total quantity. In addition, the high salt content of arid soils can be cause of stress and conduce to a low microbiological activity. ${ }^{56}$ Acknowledge of the spectrum of enzymatic activities of a soil is important since it will indicate the potential of that soil to allow the basic biochemical processes necessary for maintenance of its fertility. In general, soil studied in this research showed a low microbiological activity, with might be even lower in more degraded soils.

In general, the soil enzymatic activity underneath soils of $N$. longiglumis, $P$. speciosa and $S$. fasciculatus was greater than that in $N$. tenuis and A. ambigua, within the vegetation patches. In the experimental plots there was also a general tendency for an increased soil enzymatic activity as species richness increased in those experimental plots. It is common than in patches where there are shrubs can occur positive effects in the herbaceous plant community, which is underneath the shrubs in arid ecosystems. ${ }^{68}$ The enzymatic activity and the microbial biomass increase under the xerophytic shrubs and under more mesic conditions. ${ }^{69}$ Plant patches mitigate the effects of the extreme conditions in the associations between the plant communities and the plants, and the soil microbial communities. They also promote soil biodiversity and ecosystem functioning in arid environments, with shrubs that actively select the specific microbial groups in the herbaceous stratum. ${ }^{69}$ Shrubs promote the activity, biomass, diversity and changes in the microbial communities in soils where the abiotic conditions are more severe (e.g., poorer soils and warm and dry conditions). ${ }^{69}$ For example, shrub roots can release water obtained from deep zones in the soil profile into more superficial soil layers of dry soils. ${ }^{70}$ The presence of shrubs stimulates also the microbial activity most likely throughout root exudates ${ }^{71}$ and their litter. ${ }^{72}$

The positive correlation between the specific richness and the soil microbial functional diversity might likely be due to differences in the rhizosfere composition among the plant species and/or to different developmental morphology stages within the same species. ${ }^{73}$ Zhang et al., ${ }^{74}$ concluded that plant species richness influenced positively the nutrient retention and enzymatic activities on the substrate. However, in studies conducted by Zhang et al., ${ }^{74}$ in wet ecosystems, species richness did not change significantly the activity of the dehydrogenase enzyme. However, studies conducted on a fern community, demonstrated that the dehydrogenase positively correlated with species richness. Herbaceous plants also showed a strong positive correlation between the species richness and functional diversity of the soil. Human activities have modified not only the composition but also the species richness of the ecosystems, given place to the concern that ecosystem functioning can be negatively affected by this loss of biodiversity. ${ }^{75}$

Experimental studies have demonstrated that the loss of plant biodiversity might negatively affect ecosystem functioning, particularly by influencing plant productivity. ${ }^{19,76-79}$ The loss of species composition and richness can also alter nutrients, and their rates of recycling and decomposition. ${ }^{76}$ However, a few studies have examined the impact of the decrease of the species composition and richness in the belowground biota ${ }^{80}$ Soil microorganisms are mostly heterotrophs. As a result, they utilize plant exudates or the plant material in the decomposition of foods. A reduction in the quantity and quality of the foods caused because of a reduction in the composition and species richness must modify the abundance, activity and the diversity of the soil microbial communities. ${ }^{81}$ The loss of a particular species or functional group can a have a greater impact in ecosystem functioning than the changes in biodiversity per se. This is important because of the loss of a species is more likely to occur in a predictable way than at random. ${ }^{82}$ In addition, identification of the plant species populations that have the greatest influence on the enzymatic activity of the soil might improve our understanding of the functional consequences of such changes. ${ }^{83-87}$

\section{Conclusions}

Our findings showed that the soil dehydrogenase activity (1) differed between different plant functional groups, (2) increased as species richness also increased, and (3) was greater at later than earlier stages of plant developmental morphology stages.

\section{Acknowledgments}

Grants to C.A.B. by Universidad Nacional del Sur (24/A196) and CONICET [PIP CONICET 11220130100165 (2013-2015)] are acknowledged. 


\section{Conflicts of interest}

The author declares there is no conflicts of interest.

\section{References}

1. Shields JA, Paul EA, Low WE, et al. Turnover of microbial tissue in soil under field conditions. Soil Biol Biochem. 1973;5(6):753-764.

2. Sajjad MH, Lodhi A, Azam F. Changes in enzyme activity during the decomposition of plant residues in soil. Pakistan Journal of Biological Sciences. 2002;5:952-955.

3. Dick WA, Tabatabai MA. Significance and potential uses of soil enzymes. In: Metting FB Jr. Editor. Soil Microbial Ecology. 1993.

4. Tabatabai MA. Soil enzymes. In: Page AL, Miller RH, et al. Editors. Methods of Soil Analysis. Part II. Madison. 1982;903-947.

5. Gianfreda L, Rao MA, Piotrowska A, et al. Soil enzyme activities as affected by anthropogenic alterations: intensive agricultural practices and organic pollution. Sci Total Environ. 2005;341(1-3):265-279.

6. Ross DJ. Some factors influencing the estimation of dehydrogenase activities of some soils under pasture. Soil Biol Biochem. 1971;3(2):97110

7. Ross DJ. Effects of storage on dehydrogenase activity of soils. Soil Biol Biochem. 1970;2(1):55-61.

8. Friedel JK, Mölter K, Fischer WR. Comparison and improvement of methods for determining soil dehydrogenase activity by using triphenyltetrazolium chloride and iodonitrotetrazolium chloride. Biol Fertil Soils. 1994;18(4):291-296.

9. Kuhur M, Gartia SK, Pate AK. Quantifying the contribution of differen soil properties on enzyme activities in dry tropical ecosystems. Journal of Agricultural and Biological Science. 2012;7(9):763-773.

10. Tabatabai MA. Soil enzymes. In: Weaver RW, Angle JS, et al. Editors Methods of Soil Analysis. Part 2. Microbiological and Biochemical Properties. Madison. 1994;775-833.

11. Armado A, Contreras F, García P, et al. Correlación de actividades enzimáticas con la respiración basal en suelos cacaoteros del occidente venezolano. Avances en Química. 2009;4(2)73-77.

12. Hill TCJ, McPherson EF, Harris JA, et al. Microbial biomass estimated by phospholipid phosphate in soils with diverse microbial communities. Soil Biol Biochem. 1993;25(12):1779-1786.

13. Wolińska A, Stępniewska Z. Microorganisms Abundance and Dehydrogenase activity as a Consequence of Soil Reoxidation Process. In: Miransari M. Editor. Soil Tillage and Microbial Activities. 2011;111143

14. Ghaly A. Mahmoud N. Optimum Conditions for Measuring Dehydrogenase Activity of Aspergillus niger Using TTC. Amer J Biochem Biotech. 2006;2(4):186-194.

15. Trasar Cepeda C, Gil Sotres F, Leiros M. Thermodynamic Parameters of Enzymes In Grassland Soils From Galicia, NW Spain. Soil Biol Biochem. 2007;39(1):311-319.

16. Naeem S, Chapin FS, Costanza R, et al. Biodiversity and ecosystem functioning: Maintaining natural life support processes. Ecological Society of America. 1999;3(4):1-11.

17. Tilman D, Knops J, Wedin D, et al. The influence of functional diversity and composition on ecosystems processes. Science. 1997;277(5330):1300 1302 .

18. Porazinska DL, Bardgett RD, Blaauw MB, et al. Relationships at the aboveground-belowground interface: plants, soil biota, and soil processes. Ecol Monogra. 2003;73:377-395.
19. Spehn EM, Joshi J, Schmid B, et al. Plant diversity effects on soil heterotrophic activity in experimental grassland ecosystems. Plant Soil. 2000;224(2):217-230.

20. Ushio M, Kitayama K, Balser TC. Tree species effects on soil enzyme activities through effects on soil physicochemical and microbial properties in a tropical montane forest on Mt. Kinabalu, Borneo. Pedobiologica. 2010;53(4):227-233.

21. Vyas D, Gupta RK. Effect of edaphic factors on the diversity of VAM fungi. Tropical Plant Research. 2014;1(1):14-25.

22. Baudoin E, Benizri E, Guckert A. Impact of growth stage on the bacterial community structure along maize roots, as determined by metabolic and genetic fingerprinting. Appl Soil Ecol. 2002;19(2):135-145.

23. Johnson D, Booth RE, Whiteley AS, et al. Plant community composition affects the biomass, activity and diversity of microorganisms in limestone grassland soil. European Journal of Soil Science. 2003;54(4):671-678.

24. Wardle DA. How plant communities influence decomposer communities. In: Bardgett RD, Usher MD, et al. Editors. Biological Diversity and Function in Soils. Cambridge University Press, Cambridge. 2005;119 138.

25. Spehn EM, Joshi J, Schmid B, et al. Aboveground resource use increases with plant species richness in experimental grassland ecosystems. Funct Ecol. 2002;14(3):326-337.

26. Yin B, Crowley D, Sparovek G, et al. Bacterial functional redundancy along a soil reclamation gradient. Applied and Environmental Microbiology. 2000;66(10):4361-4365.

27. Rodríguez Loinaz G, Onaindia M, Amezaga I, et al. Relationship between vegetation diversity and soil functional diversity in native mixed-oak forests. Soil Biol Biochem. 2008;40(1):49-60.

28. Cabrera AL. Regiones fitogeográficas Argentinas. Enciclopedia Argentina de Agricultura y Jardinería. Acme SACI. Buenos Aires. 1976.

29. Giorgetti HD, Busso CA, Montenegro OA, et al. Cattle raising in central, semiarid rangelands of Argentina. Rangelands. 2006;28(1):32-36.

30. Kugler N, Giorgetti HD, Rodríguez GD, et al. Cow performance in conventional and early weaning herds in north Patagonia, Argentina. Rangelands. 2008;30(1):12-16.

31. Ithurrart LS, Busso CA, Montenegro OA, et al. Total soil available nitrogen under perennial grasses after burning and defoliation. Russ $J$ Ecol. 2017;48(2):122-133.

32. Giorgetti H, Montenegro OA, Rodríguez GD, et al. The comparative influence of past management and rainfall on range herbaceous standing crop in east-central Argentina: 14 years of observations. J Arid Environ. 1997;36(4):623-637.

33. Distel RA, Boo RM. Vegetation states and transitions in temperate semiarid rangelands of Argentina. In: West N, editor. Proceedings of the Vth International Rangeland Congress. 1996.

34. Saint Pierre C, Busso CA, Montenegro OA, et al. Root proliferation in perennial grasses of low and high palatability. Plant Ecol. 2002;165(2):161-169.

35. Boó RM, Peláez DV. Ordenamiento y clasificación de la vegetación en un área del sur del Distrito del Caldén. Bol Soc Arg Bot. 1991;27(3-4):135141.

36. Cano E. Pastizales naturales de La Pampa. Descripción de las especies más importantes. Tomo I Convenio AACREA-Provincia de La Pampa, Buenos Aires. 1998

37. Busso CA, Fernández OA. Arid and Semiarid Rangelands of Argentina. Climate Variability Impacts on Land Use and Livelihoods in Drylands. 2017;261-291. 
38. Passera CB, Cavagnaro JB, Sartor CE. Plantas C3; C4 y CAM nativas del Monte árido argentino, adaptaciones y potencial biológico. C4 y CAM Características Generales y uso en programas de desarrollo de tierras áridas y semiáridas. Homenaje al Dr. J. Lopez Gorgé. Consejo Superior de Investigaciones Científicas. 2010;165-176.

39. Torres YA, Busso CA, Montenegro OA, et al. Plant growth and survival of five introduced and two native/naturalized perennial grass genotypes exposed to two defoliation managements in arid Argentina. Grass and Forage Science. 2014;69(4):580-595.

40. Torres YA, Busso CA, Montenegro OA, et al. Root proliferation in perennial grasses in arid Patagonia, Argentina. $J$ Arid Land. 2014;6(2):195-204

41. Cassida LE. Microbial metabolic activity in soil as measured by dehydrogenase determinations. Appl Environ Microbiol. 1977;34(6):630 636.

42. Alef K, Nannipieri P. Enzyme activities: Catalase activity. In: Alef K, Nannipieri P, editors. Methods in applied soil microbiology and biochemistry, Academic Press, London. 1998;576.

43. Dunnett CW. A Multiple Comparison Procedure for Comparing Several Treatments with a Control. Journal of the American Statistical Association. 1955;50(27):1096-1121.

44. Cardillo D, Busso C, Ambrosino M, et al. Respiración microbiana en suelos de la Provincia Fitogeográfica del Monte. 2014.

45. Bastida F, Barberá GG, García C, et al. Influence of orientation, vegetation and season on soil microbial and biochemical characteristics under semiarid conditions. Appl Soil Ecol. 2008;38(1):62-70.

46. Visser S, Parkinson D. Microbial respiration and biomass in a lodgepole pine stand acidified with elemental sulphur. Can J For Res. 1989;19(8):955-961.

47. Brzezinska M, Stepniewska Z, Stepniewski W. Soil oxygen status and dehydrogenase activity. Soil Biol Biochem. 1998;30(13):1783-1790.

48. Qureshi S, Richards BK, Hay AG, et al. Effect of microbial activity on trace element release from sewage sludge. Environ Sci Technol. 2003;37(15):3361-3366.

49. Ramos E, Zúñiga D. Efecto de la humedad, temperatura y $\mathrm{Ph}$ del suelo en la actividad microbiana a nivel de laboratorio. Ecología Aplicada. 2008;7(1-2):123-130.

50. Gili P, Marando G, Irisarri J, et al. Actividad biológica y enzimática en suelos afectados por sales del Alto Valle de Río Negro y Neuquén. Rev Argen Microb. 2004;36(4):187-192.

51. Skujins JJ. History of abiotic soil enzyme research. In: Burns RG, Editor Soil Enzyme Academic Press, New York. 1978;1-49.

52. Frankenberger WT Jr, Dick WA. Relationships between enzyme activities and microbial growth and activity indices in soil. Soil Sci SocAmer J. 1983;47(5):945-951

53. Jenkinson DS, Ladd JN. Microbial biomass in soil: measurement and turnover. Soil Biochemistry. 1981;415-471.

54. Nannipieri P, Pechozzini F, Arcara PG, et al. Changes in amino acids, enzyme activities and biomass during soil microbial growth. Soil Science. 1979;127(1):26-34.

55. Brookes PC, Tate KR, Jenkinson DS. The adenylate energy charge of the soil microbial biomass. Soil Biol Biochem. 1983;15(1):9-16.

56. García C, Hernández T, Costa F. Microbial activity in soils under Mediterranean environmental conditions. Soil Biol Biochem. 1994;26(9):1185-1191.
57. Nannipieri P, Greco S, Ceccanti B. Ecological significance of the biological activity in soil. Soil Biochem. 1990;6:293-355.

58. Beyer L, Wachendor C, Balzen FM, et al. The effect of soil texture and soil management on microbial biomass and soil enzyme activities in arable soils of Northwest Germany. Agrobiology Research. 1992;45:276-283.

59. Lipson DA, Steven K Schmidt, Monson RK. Links between microbial population dynamics and nitrogen availability in an alpine ecosystem. Ecology. 1999;80(5):1623-1631.

60. Cao D, Shi F, Koike T, et al. Halophyte plant communities affecting enzyme activity and microbes in saline soils of the yellow river delta in China. Soil Air Water. 2014;42(10):1433-1440.

61. Agnelli A, Ascher J, Corti G, et al. Distribution of microbial communities in a forest soil profile investigated by microbial biomass, soil respiration and DGGE of total and extracellular DNA. Soil Biol and Biochem. 2004;36(5):859-868.

62. Fontaine S, Marotti A, Abbadie L. The Priming Effect of Organic Matter: A Question of Microbial Competition? Soil Biol Biochem. 2003;35(6):837-843.

63. Vázquez Yanes C, Batis Muñoz AI, Alcocer Silva MI, et al. Árboles y arbustos potencialmente valiosos para la restauración ecológica y la reforestación. CONABIO. 1999.

64. Niklaus PA, Kandeler E, Leadley PW, et al. A link between plant diversity, elevated $\mathrm{CO}_{2}$ and soil nitrate. Oecologia. 2001;127(4):540-548.

65. Quilchano C, T Marañón. Dehydrogenase activity in Mediterranean forest soil. Biology and Fertility of Soils. 2002;35(2):102-107.

66. Domsch KH, Jagnow G, Anderson TH. An ecological concept for the assessment of side-effects of agrochemicals on soil microorganisms. Residue Reviews. 1983;86:65-105.

67. Mirás Avalos JM, Sande Fouz P, Vidal Vázquez E. Actividad deshidrogenasa en dos posiciones topográficas de un suelo de cultivo. Cademos do Lab Xeolóxico Laxe. 2007;32:151-163.

68. Busso CA, Bonvissuto GL, Torres YA. Germination and seedling establishment of grasses and shrubs in arid Patagonia, Argentina. Land Degr Dev. 2000;23:116-129.

69. Hortal S, Bastida F, Moreno JL, et al. Benefactor and allelopathic shrub species have different effects on the soil microbial community along an environmental severity gradient. Soil Biol Biochem. 2015;88:48-57.

70. Caldwell MM, Dawson T, Richards J. Hydraulic lift: consequences of water efflux from the roots of plants. Oecologia. 1998;113(2):151-161.

71. Haichar FZ, Marol C, Berge O, et al. Plant host habitat and root exudates shape soil bacterial community structure. ISME Journal. 2008;2(12):1221-1230.

72. Zhang D, Hui D, Luo Y, et al. Rates of litter decomposition in terrestrial ecosystems: global patterns and controlling factors. J Plant Ecol. 2008;1(2):85-93

73. Benizri E, Amiaud B. Relationship between plants and soil microbial communities in fertilized grasslands. Soil Biol Biochem. 2005;37(1):20552064.

74. Zhang CB, Wang J, Liu WL, et al. Effects of plant diversity on nutrient retention and enzyme activities in a full scale constructed wetland. Bioresource Technology. 2010;101(6):1686-1692.

75. Loranger Merciri G, Barthes L, Gastine A, et al. Rapid effects of plant species diversity and identity on soil microbial communities in experimental grassland ecosystems. Soil Biol Biochem. 2006;38(8):23362343 
76. Loreau M, Naeem S, Inchausti P, et al. Biodiversity and ecosystem functioning: current knowledge and future challenges. Science. 2001;294(5543):804-808.

77. Tilman D, Wedin D, Knops J. Productivity and sustainability influenced by biodiversity in grassland ecosystems. Nature. 1996;379(6567):718720 .

78. Hector A, Schmid B, Beierkuhnlein C, et al. Plant diversity and productivity experiments in European grasslands. Science. 1999;286(5442):11231127

79. Schmid B, Joshi J, Schläpfer F. Empirical evidence for biodiversityecosystem functioning relationships. In: Kinzig A, Pacala S, et al. Editors. Functional Consequences of Biodiversity: Experimental Progress and Theoretical Extensions. Princeton University Press, Princeton. 2002;120 150

80. Wardle DA, Bardgett RD, Klironomos JN, et al. Ecological linkages between aboveground and belowground biota. Science. 2004;304(5677):1629-1633.

81. Hooper DU, Bignell DE, Brown VK, et al. Interactions between aboveground and belowground biodiversity in terrestrial ecosystems: patterns, mechanisms, and feedbacks. Bio Science. 2000;50(12):10491061.
82. Grime JP. Declining plant diversity: empty niches or functional shifts? J Veg Sci. 2002;13(4):457-460.

83. Bardget RD, Mawdsle JL, Edwards S, et al. Plant species and nitrogen effects on soil biological properties of temperate upland grasslands. Funct Ecol. 1999;13(5):650-660.

84. INTA CIRN. Mapa de suelos de la provincia de Buenos Aires. Instituto Nacional de Tecnología Agropecuaria. Centro de Investigación de Recursos Naturales. Instituto de Evaluación de Tierras, Buenos Aires. 1989

85. King DA. The adaptive significance of tree height. American Naturalist. 1990;135(6):809-828.

86. Ping Gong. Dehydrogenase activity in soil: a comparison between the INT and TTC assay. Soil Biol Biochem. 1997;29(2):673-674.

87. Wolińska A, Stępniewska Z. Dehydrogenase Activity in the Soil Environment. Biochemistry, Genetics and Molecular Biology "Dehydrogenases". In: Canuto RA. Editor. IntechOpen, Lublin, Poland. 2010;183-210. 